\title{
Mainstreaming and Beyond: Policy Capacity and Climate Change Decision-Making
}

\author{
ADAM WELLSTEAD ${ }^{1 *}$, RICHARD STEDMAN $^{2}$ \\ Volume 3, Spring 2015 \\ http://dx.doi.org/10.3998/mjs.12333712.0003.003 \\ 'Department of Social Sciences, Michigan Technological University, Houghton, MI 49931 \\ ${ }^{2}$ Department of Natural Resources, Cornell University, Ithaca, NY \\ *Corresponding author: Adam Wellstead, awellste@mtu.edu
}

\section{ABSTRACT}

Mainstreaming involves integrating climate adaptation measures into existing policies and programs. This article reviews the policy process and policy capacity of government organizations and suggests that both need to be incorporated into climate change adaptation assessments. A critical part of mainstreaming is evidencebased decision-making, which emphasizes that decision makers should have the best available information in order to make knowledgeable decisions. This requires policy work that involves a wide variety of statistical methods, applied research, and advanced modeling techniques to gauge broad public opinion and attitudes as well as more routine research techniques. A review of previous past quantitative studies conducted mainly in Canada identifies factors driving policy capacity within government departments responsible for formulating, choosing, implementing, and evaluating climate change adaptation policies and programs. Policy capacity has traditionally been objectively measured and includes indicators such as the number of policy staff, their education levels, resources available, roles and tasks, and ongoing training. More attention needs to be paid to the subjective perceptions of individuals who undertake policy work, in particular the attitudes towards the policymaking process. This paper concludes by proposing a policy capacity framework that includes individual, organizational, and sectoral policy capacity considerations. 


\section{Introduction}

Natural disasters and the inability of governments to collectively mitigate greenhouse gas emissions have amplified public concern about the need for on-theground adaptation measures. Adaptation to climate change has become an agenda item for many governments in the United States (Bierbaum et al. 2013). This is in part demonstrated by a spate of government-led climate change vulnerability and risk assessments, studies, and strategies. Practitioners and academics frequently cite the importance of "mainstreaming" climate change adaptation. Simply put, mainstreaming is integrating climate adaptation measures into existing policies and programs (Lim and Spanger-Siegfried 2004). In this paper, we argue that the policy process in general-and more specifically the policy capacity of government organizations - needs to be incorporated into ongoing assessments of climate change adaptation if mainstreaming is to occur. Currently, assessments often treat policy making as a quasi-automatic response or do not properly account for political or policy factors (Wellstead, Howlett, and Rayner 2013).

As a discipline, policy science is relatively young. It differentiates itself from policy analysis, a technical approach to providing advice on the choosing of alternatives, by focusing on explaining why certain alternatives are chosen and others are not (Simeon 1976: 550). In the first issue of Policy Sciences, Harold Lasswell argued that this new approach should be multi-disciplinary, oriented towards problem solving, and normative (Lasswell 1970; Howlett, Ramesh, and Perl 2009). Toward that end, Lasswell sought to develop a model that would examine the "interdependence between the functional components of the policy process" (1970: 9). Since then, a number of other policy process approaches have emerged, such as the advocacy coalition framework, institutional rational choice, and punctuated equilibrium theory (see Schlager and Blomquist 1996; Sabatier and Weible 2014). However, the policy cycle is the starting point for all policy students and many practitioners (see Birkland 2005; Howlett, Ramesh, and Perl 2009; Wu et al. 2011; Cairney 2014; Hill 2014). The cycle includes agenda setting, policy formulation, decision-making, implementation, and evaluation (Figure 1).

Policy capacity within government organizations that are engaged in the various stages of the policy process is an important but often-overlooked consideration. There are several definitions of policy capacity. Honadle (1981: 578) defines it as "the ability to: anticipate and influence change; make informed intelligent decisions about policy; develop programs to implement policy; attract and absorb resources; manage resources; and evaluate current activities to guide future action." Others are 


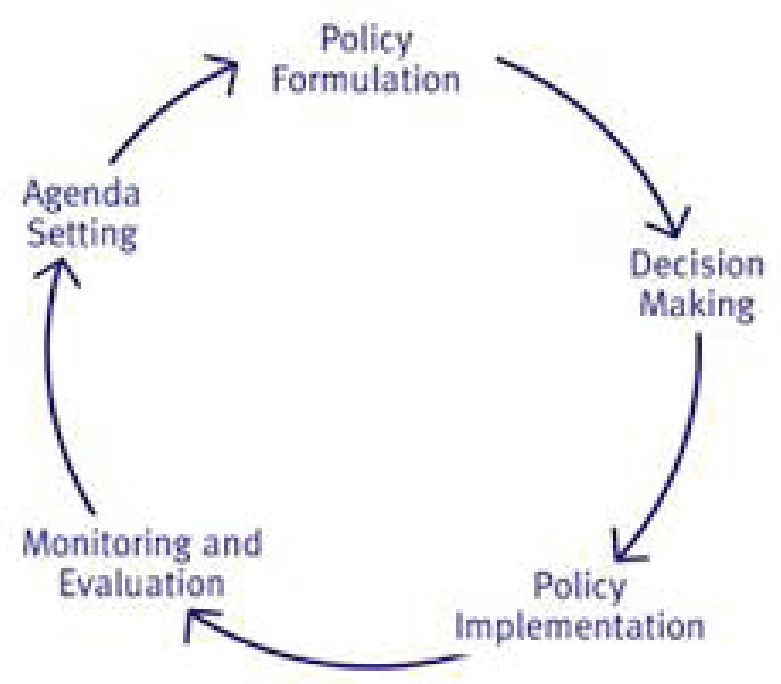

Figure 1 - The Policy Cycle

also concerned with the ability of government agencies to respond to change (Weiss 1998), the intellectual and organizational resources of the state (Cummings and Nørgaard 2004), knowledge management and organizational learning (Common 2006), or policy formulation (Goetz and Wollmann 2001).

We argue that policy capacity research that has been undertaken primarily in Canada should also be applied in a U.S. climate change adaptation context. To support this assertion, we introduce the policy cycle as necessary companion to the National Climate Change Assessment's Adaptation Process. We then give an overview of drivers of policy work and policy capacity found in past quantitative studies.

\section{Looking beyond 'stakeholderism': The policy cycle revisited}

The comprehensive 2014 Third National Climate Assessment (hereafter "the Assessment") is particularly informative because it summarizes what federal, state, municipal, and tribal governments - as well as private organizations - are doing to address climate change vulnerability across multiple sectors. For example, in the forestry sector, which has been affected by climate change-related events such as wildfires and mountain pine beetle outbreaks, the US Forest Service developed the National Roadmap for Responding to Climate Change and a Guidebook for Developing Adaptation Options (USDA Forest Service 2010; USDA Forest Service 2011a). Similarly, 
the State of Colorado addressed climate change-related wildfires and drought in its climate change strategy (Colorado 2007). There have also been cross-jurisdictional collaborative efforts such as the Northwoods Climate Change Response Framework, which spans three states (Michigan, Minnesota, and Wisconsin) and involves government agencies, academia, and NGOs (USDA Forest Service 2011b).

The Assessment presents a "generalized climate process" cycle that is common in many climate change adaptation initiatives. It consists of five discrete stages: identifying and understanding risk, vulnerabilities, and opportunities; developing options; implementing actions; monitoring outcomes; reevaluating strategies; and continual stakeholder engagement (Figure 2). Most current efforts focus on the first stage, assessing risks (Bierbaum et al. 2014). Although such assessments produce a vast wealth of knowledge, more information about risk and vulnerabilities will not necessarily lead to better policies, especially regarding a complex issue such as climate change adaptation (Geyer and Rihani 2010). A challenge that all governments will need to grapple with is precisely how to use management recommendations found in climate change assessments to develop new policies or amend existing programs.

At the center of the Assessment's adaptation process cycle in Figure 1, according to Bierbaum et al. (2014), is stakeholder engagement. They state:

Participatory approaches support the integration of stakeholder perspectives and context-specific information into decision-making. This approach can include having community members and governing institutions work collectively to define the problem and design adaptation strategies that are robust while being sensitive to stakeholder values. (Bierbaum et al. 2014: 28)

Although stakeholder perspectives are valuable, it is critical to pay greater attention to the government's role throughout the process, and more specifically its policy capacity. The Assessment's authors state that to date, very little has been achieved in the other five mainstreaming stages (developing options, implementing actions, monitoring outcomes, reevaluating strategies, and stakeholder engagement). A brief illustration from the forest sector provides an example of mainstreaming. Conservation and sustainable forest management are broad long-term policy goals within this sector. Biodiversity conservation is a specific sustainable forest measure. A particular biodiversity issue is the decline of the whitebark pine (Pinus albicaulis), an important component of western high-elevation forests that has been declining in the United States due to the combined effects of mountain pine beetle (Dendroctonus ponderosae) outbreaks, fire exclusion policies, and the spread of the exotic disease white pine blister rust (Keane et al. 2012). 


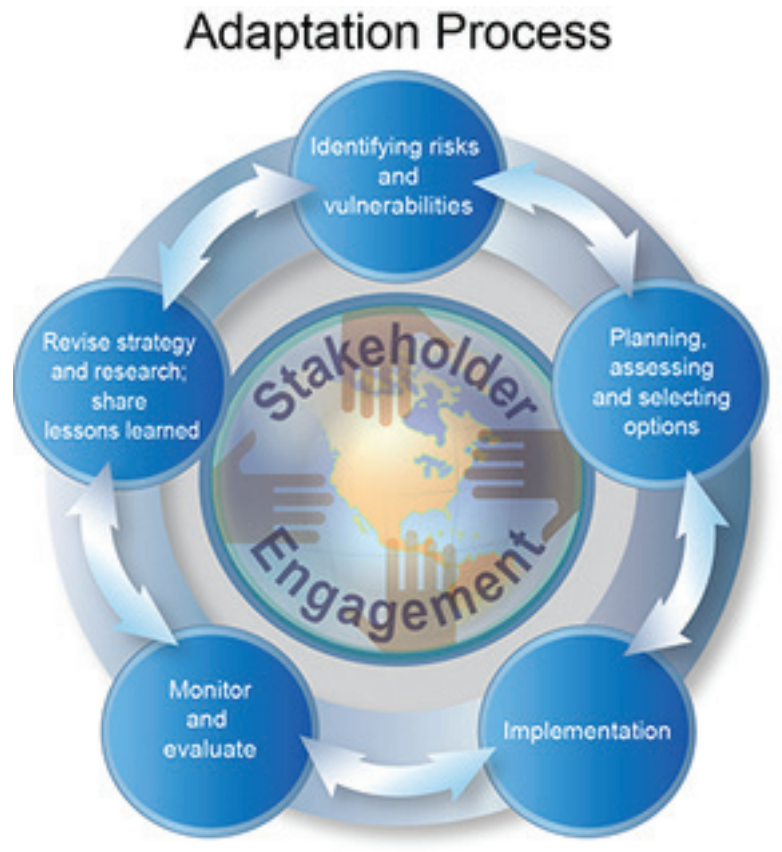

Figure 2. National Climate Change Assessment's adaptation process Source: Bierbaum et al. (2014)

In addition to addressing these concerns, the Forest Service is also considering how climate change might affect the whitebark pine. In the Range-Wide Restoration Strategy for Whitebark Pine, Keane et al. (2012: 38) state: "In anticipation of climate change, transfer of rust resistant seed sources should be unidirectional from colder (northerly latitude, higher elevations, or both) to milder climates within the local temperature envelope and seed zone." One possible management option, according to the US Forest Service, is assisted tree migration, namely moving tree species to non-native habitats. Stein et al. (2014) call assisted migration a "climate-smart design consideration." They also acknowledge that existing forest management policies need to be changed and that the policy environment needs to be accounted for.

We argue that issues relating to the policy environment and policy capacity, which are not discussed in the Assessment, need to enter into the climate change adaptation discourse if successful mainstreaming and implementation are to occur. Bierbaum et al. (2013) state that "research on policy processes . . . in the United States to date has been understudied and underappreciated" (p. 393). Similarly, Dovers and Hezri (2010) point out that adaptation research focuses predominantly on what ought to happen rather than how that might be achieved. 
The policy literature acknowledges the role of stakeholders in shaping public policy making; however, it also incorporates the government's involvement. The interaction and relationship between state and society is highly variable and remains one of the most contested areas in political science (Chilcote 1994). For example, a "new governance" literature has emerged that stresses the increased role of stakeholder involvement in policy making (Savoie 2003). This environment is said to include (1) a more diverse set of societal-based actors equipped with valuable resources who seek to provide policy guidance to government (Halligan 1995; Koliba and Gradja 2009; Hamburger and Weller 2012); (2) the public's declining trust in the decision-making monopolies held by politicians and bureaucracies, and a concomitant desire to be more directly involved in the policymaking process (Peters and Pierre 1998); (3) a general trend towards privatization of operations and program delivery; and finally, (4) the development of more localized governance arrangements emphasizing the role of networks that stress a greater equality among societal and government actors (Prince 2007). Despite this changing policy environment, empirical research has challenged the new governance thesis whereby governments play a minimal role. Capano's (2011) study of education policy across four European countries found the state to be very much engaged, albeit unevenly. Doelle et al.'s (2012) study of climate change governance in Canada and the United States concluded that societal actors successfully shape both policy processes and outcomes; even so, government still plays the leading role. Their study found no straightforward shift in governance towards stakeholder dominance.

Table 1 compares the adaptation process, the policy cycle, and the role that government and societal actors play at each of the stages. Howlett, Ramesh, and Perl's (2009) policy cycle-actor hourglass reveals that at each stage of the policy cycle, the number of stakeholders and government actors differs, as well as the scope of their involvement (Figure 3). At the agenda-setting and evaluation stages, the policy universe (all policy actors) are typically engaged, whereas policy formulation and implementation typically involve only those actors in the policy subsystem (e.g., the agriculture sector, the forest sector, the transportation sector).

At all five stages, the inclusion of policy work can provide a more nuanced understanding of government's role. This work is absent in climate change assessments and severely neglected in the mainstreaming literature. This oversight can be illustrated by the long list of barriers to adaptation discussed in the Assessment. Barriers are "obstacles that can delay, divert, or temporarily block the adaptation process" (Bierbaum et al. 2014: 683). Bierbaum et al. (2014) identify as barriers the lack of climate education for professionals and the public, as well as the lack of usable 
and accessible existing information. Additionally, a mismatch of decision-making timescales and future climate projections is often seen as problematic, as are institutional inflexibility, rigid laws and regulations, and the absence of a legal mandate to act (Bierbaum et al. 2014). A lack of policy capacity, however, is not identified as a barrier.

TABLE 1. Comparing the adaptation process and the policy cycle.

\begin{tabular}{|c|c|c|c|}
\hline $\begin{array}{l}\text { Adaptation process } \\
\text { (Bierbaum et al. 2014) }\end{array}$ & $\begin{array}{c}\text { Policy cycle } \\
\text { (Howlett, Ramesh, and Perl } \\
\text { 2009; Wu et al. 2011) }\end{array}$ & $\begin{array}{l}\text { Key actors } \\
\text { involved }\end{array}$ & $\begin{array}{l}\text { Role of government and societal } \\
\text { actors in the policy cycle }\end{array}$ \\
\hline $\begin{array}{l}\text { Identifying risks and } \\
\text { vulnerabilities }\end{array}$ & Agenda setting & Policy universe & $\begin{array}{l}\text { Many actors compete to get their } \\
\text { issues on the policy agenda. }\end{array}$ \\
\hline $\begin{array}{l}\text { Developing options } \\
\text { "Mainstreaming" }\end{array}$ & Policy formulation & Policy subsystem & $\begin{array}{l}\text { A limited number of government and } \\
\text { societal actors from specific sectors } \\
\text { engage with one another to develop } \\
\text { policies and programs to address a } \\
\text { specific issue. }\end{array}$ \\
\hline Not present & Decision-making & Decision-making & $\begin{array}{l}\text { The decision to proceed is typically } \\
\text { made by key government decision } \\
\text { makers. }\end{array}$ \\
\hline Implementation & Implementation & Policy subsystem & $\begin{array}{l}\text { The implementation of a policy or } \\
\text { program in a particular sector is } \\
\text { carried out in a host of different ways } \\
\text { and often involves societal actors. }\end{array}$ \\
\hline $\begin{array}{l}\text { Monitoring outcomes and } \\
\text { reevaluating strategies }\end{array}$ & Evaluation & Policy universe & $\begin{array}{l}\text { Implementation involves many } \\
\text { government and societal actors from } \\
\text { across different sectors. Evidence- } \\
\text { based evaluation is needed. }\end{array}$ \\
\hline
\end{tabular}

\section{What are policy work and policy capacity?}

There is a substantial public administration literature on policy capacity and those responsible for providing it. The policy-worker profession was first described in Dror's 1967 case study of the U.S. Planning-Programming Budgeting System (PPBS). Dror (1967) saw policy workers as instrumental in improving the decisionmaking function in complex government agencies such as the PPBC. For example, he portrayed policy analysis as a rationalistic undertaking consisting of career civil servants objectively presenting information to policymakers or 'speaking truth to power' (Wildavsky 1979; Radin 1997). In the face of a changing policy-making environment in the U.S. during the mid-1970s, Meltsner (1976) was the first to develop a more multifaceted policy analytical typology. He contended that analysts' 


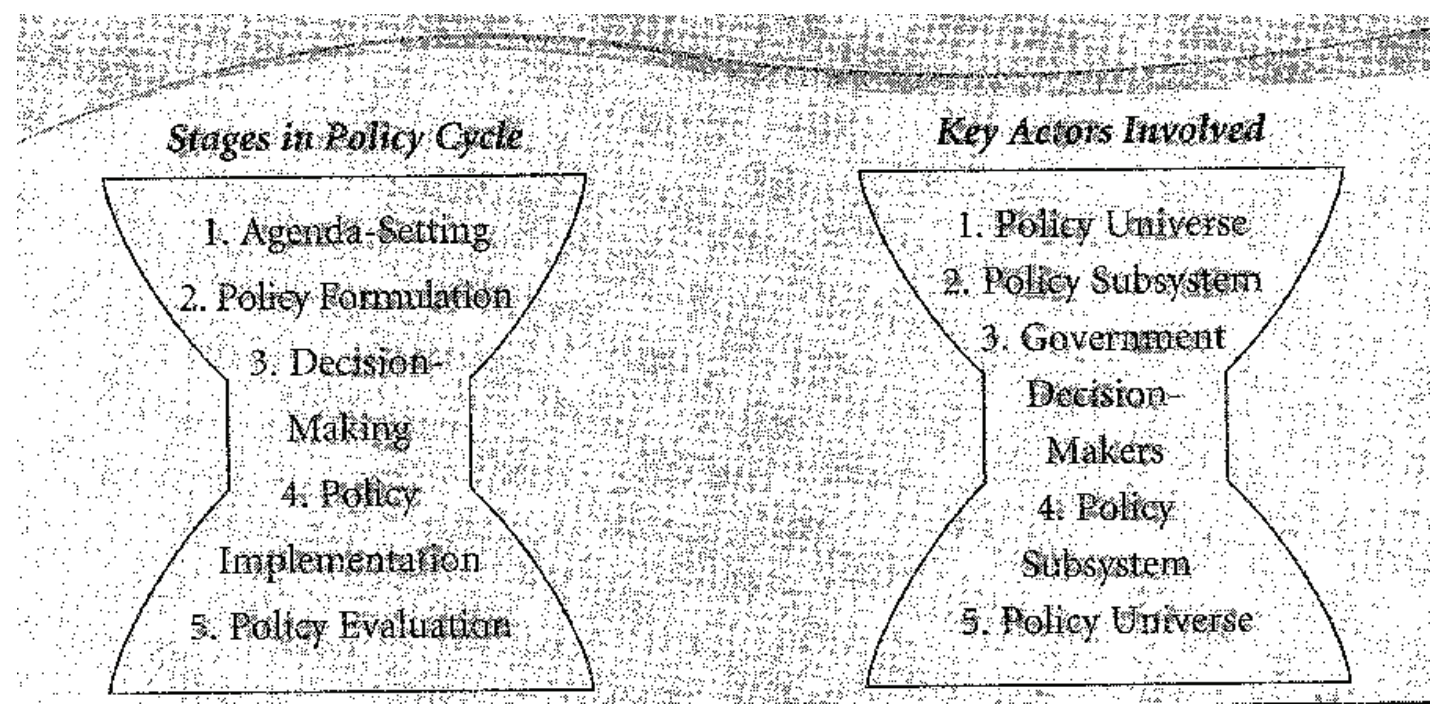

Figure 3. The policy cycle-actor hourglass.

Source: Howlett, Ramesh, and Perl (2009: 13). Used with permission.

particular policy analytical style depended on a combination of both political and technical skills that in turn were shaped by a unique combination of education, professional training, beliefs, and personal motivations (see also Hoppe \& Jeliazkova 2006; Mayer et al. 2004; Durning and Osuna 1994; Jenkins-Smith 1982; Dluhy 1981). Mayer et al.'s (2004: 170) overview of Dutch policy work further elaborated this theme by noting that the "the variety and multi-faceted nature of policy analysis makes it clear that there is no single, let alone 'one best', way of conducting policy analyses." The recent trends in a changing governance environment point to the growing complexity of public policy making and a shift in fundamental styles of analysis. Administrators and analysts are expected to engage in more consultation, consensus building, and public dialogue than before (Prince 2007). Furthermore, analysts now use a wider set of policy instruments than in the past, particularly procedural ones such as facilitating private partnerships, roundtables, and funding arrangements with organized societal groups in their work (Lindquist 1992; de Bruijn and Porter 2004; Goldsmith and Eggers 2004; Howlett and Lindquist 2004). There is now less space for "traditional" technical policy analysis, which Mayer et al. (2004) term researching and analyzing, designing and recommending, and clarifying arguments and values. Instead, there has been a shift towards activities related to providing strategic advice, democratizing policy processes, and mediating policy disputes. 
At its core, policy capacity focuses on the ability of public policy organizations to produce sound analysis and advice to inform their policy-making activities (Prince 2007). Policy-work activities, we argue, play a critical role in "mainstreaming" activities as well as other aspects of the policy cycle. Policy work is a term that captures both the applied practice of policy-what it is that policy professionals actually do-as well as a field of research. It encompasses a large set of activities concerned with policy making that extend beyond policy analysis and the provision of advice, and may include the construction and maintenance of relations among stakeholders (Colebatch 2006). Policy work is also fluid in that it is in part contingent upon the policy situations and context within which it is undertaken, those who are engaged in it, and a broader set of assumptions and preferences about how the policy-making process itself should be understood (Colebatch 2006: 309).

\section{Towards a policy capacity research mainstreaming agenda}

There is a long-standing literature empirically examining the changing roles of those engaged in policy work (for example, Radin 1997; Page and Jenkins 2005; Colebatch and Radin 2006). As the title of Page and Jenkins' 2005 book, Policy Bureaucracy: Government with a Cast of Thousands, suggests, there are many people who undertake policy work within government agencies. The availability of government employees' contact information has recently led to a surge of survey-based scholarship that has been undertaken mainly in Canada (Howlett 2009; Wellstead, Stedman, and Lindquist 2009) but has included studies in the Czech Republic (Veselý 2013) and in Australia (Head et al. 2014). This scholarship has identified a number of key variables affecting policy work and policy capacity, which are highlighted below.

One strand of this research uses observable "objective" indicators to measure policy capacity (Manitoba 2001; Ontario Executive Research Group 2001; Hicks and Watson 2007). Inputs such as the number of policy staff, their education levels, resources available, roles and tasks, and ongoing training have been compared to outputs such as the number of reports/briefing notes or assessments of program success. Wellstead, Stedman, and Howlett (2011) found that policy workers performed a wide variety of tasks such as researching and analyzing, designing and recommending, clarifying arguments and values, providing strategic advice, democratizing policy processes, and mediating policy disputes).

Another important area of policy work is evidence-based policy, which empha- 
sizes that decision makers should have the best available information in order to make knowledgeable decisions (Howlett 2009). Evidence-based policy is concerned with whether or not policies actually work. According to Davies (2004), government programs often are implemented with little regard to evidence; as a result, they fail to address critical problems, even though they cost billions of dollars. However, rigorous studies have identified highly effective program models and strategies ("interventions"), suggesting that a concerted government effort to build the number of these proven interventions and to spur their widespread use could bring about better policy results. As a methodology, evidence-based policy advocates a more rational, rigorous and systematic approach through the integration of experience, judgment and expertise with the best available external evidence (Howlett and Craft, 2013). It shifts policy making from opinion-based decision making towards decisions based on the judgments of experts that constitute high-quality valid and reliable evidence. Therefore, policy work should permit a government to conduct or access basic research. Policy workers should be able to employ statistical methods, applied research, and advanced modeling techniques to gauge broad public opinion and attitudes and integrate information into decision-making (Howlett 2009). Table 2 provides examples from recent studies that illustrate the type of policy work undertaken at each stage of the policy cycle.

In the short term, greater emphasis is needed in two areas of policy work: (1) understanding the technical challenges associated with developing policy instruments and programs that permit mainstreaming to occur, and (2) developing approaches for evidence-based climate change policy. Both of these challenges will fall more to policy workers in government agencies than to stakeholders. The importance of policy work means that an agency's policy capacity needs to be better understood.

Recent research into these objective measures has expanded to include analytical, managerial, and political capacity skills and resources across individual-, organizational-, and sector-level units of analysis (Table 3).

A second approach is to measure the quality aspect of policy capacity, namely the subjective perceptions of individuals who undertake policy work. From a number of surveys of policy workers, quantitative models of perceived policy capacity have been developed, including Ordinary Least Squares (OLS) regression and structural equation models. They have found that measured perceived policy capacity has been influenced by a number of factors. The first is the nature of the roles and tasks listed in Table 2. The policy worker's environment also plays an important role; this includes the geographic (national, provincial, local), temporal (long-term work versus short-term work or "fire fighting"), and the nature of the issues (Howlett and 
TABLE 2. Policy work and the policy cycle.

\begin{tabular}{ll}
\hline Policy cycle stages & Examples of policy roles and tasks \\
\hline Agenda setting & Identifying policy issues \\
& Identifying policy options \\
& Environmental scans \\
& Consulting with the public \\
& Appraising policy options \\
Policy formulation & Collecting policy-related data \\
& Collecting policy-related information \\
& Conducting policy-related research \\
& Negotiating with stakeholders \\
& Preparing position papers \\
& Comparing policy options \\
& Decision matrices \\
& High-level briefing \\
Decision making & Negotiating with central agencies \\
& Department planning \\
& Implementing or delivering policies or programs \\
& Negotiating with program managers \\
Consulting with stakeholders \\
Legal analysis \\
Policy evaluation skills (e.g., cost benefit analysis, risk assessment) \\
Risk-based tools and techniques \\
Evidence-based policy \\
\hline
\end{tabular}

Wellstead 2012). Howlett and Wellstead (2011) found that issues varied according to whether they were technical (i.e., issues that require specialist or technical knowledge), consultative (e.g., issues that demand input from society-based organizations), routine (e.g., issues that have a single, clear, relatively simple solution), or complex or wicked (e.g., issues for which it is difficult to identify a single, clear, simple solution). Mayer et al. (2004) argued that the role of contemporary policy workers in a new governance environment should include greater engagement with stakeholders (e.g., NGOs and think tanks). The Canadian evidence, however, showed that in reality, insular government-centered networks focused on their own departmental senior management (Wellstead, Stedman, and Howlett 2011).

The most significant finding is the contribution of attitudinal predispositions to perceived policy capacity. The connection between attitudes towards governance and climate change, associated cognitions, and structural factors is important to understanding policy response and the engagement of policy makers in climate change-related work. The growing politicization of civil service and its impact on policy work (Savoie 2003) have also been well documented (Wellstead, Stedman, 
TABLE 3. Policy Capacity Framework

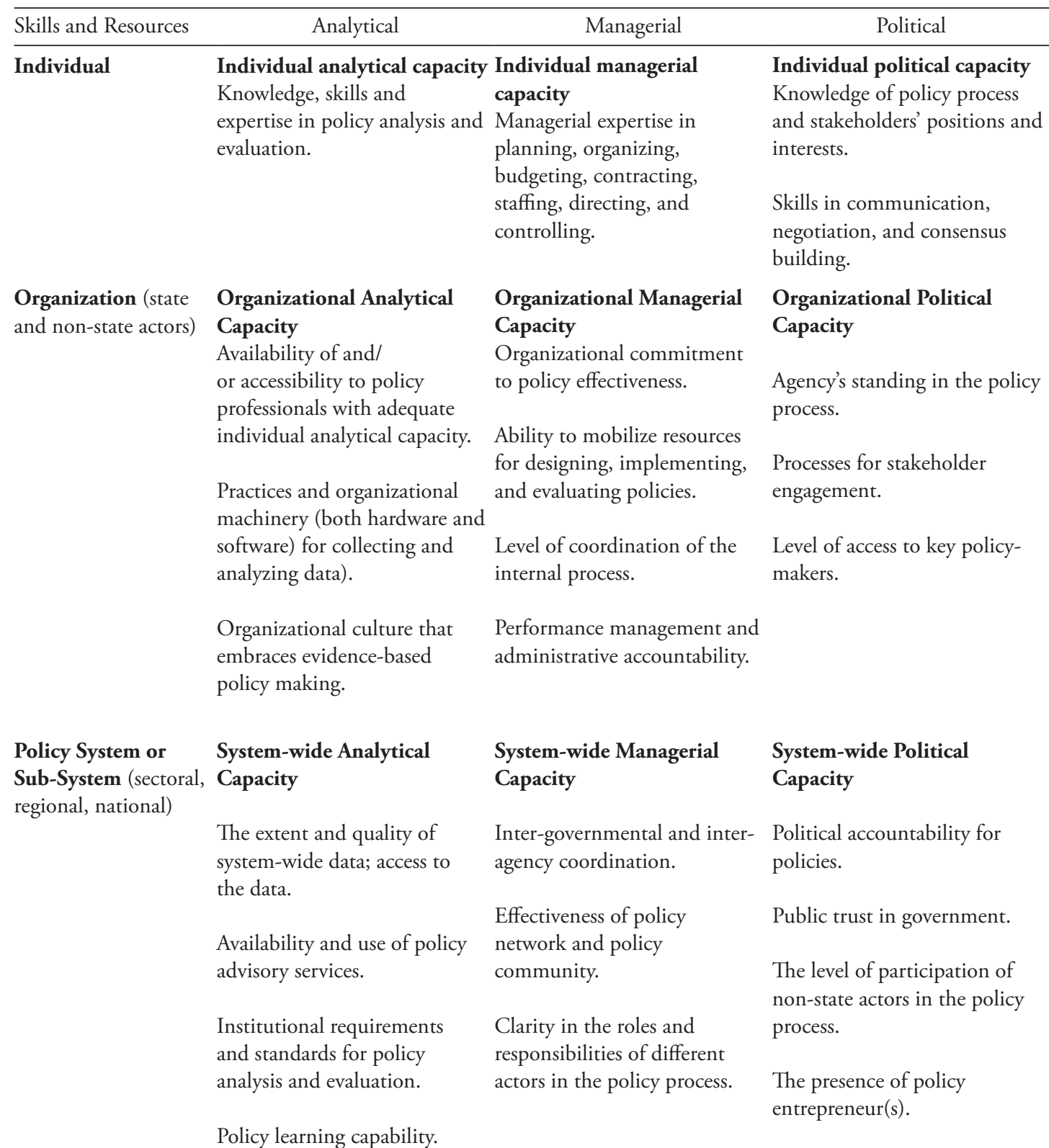

Source: Wu, X., Ramesh, M., and M. Howlett (Forthcoming) 
and Howlett 2011). Some prominent examples of measureable attitudes appear in Table 4.

TABLE 4. Examples of policy-based attitudes affecting perceived policy capacity.

Urgent day-to-day issues seem to take precedence over thinking 'long term.'

Policy decisions increasingly seem to be those that are most politically acceptable.

Policy problems increasingly require strong technical expertise.

Those who have more authority in decision making usually have less specialized technical expertise.

An important role of government is to foster involvement in the policy process by other non-governmental organizations.

Wellstead and Stedman's (2014) examination of Canadian climate change policy workers found that key climate change-oriented attitudes were also important when considering perceived policy capacity. Their OLS model found that when information regarding adaptation to climate change was understood within a respondent's government agency and they perceived that the body of knowledge regarding adaptation to climate change was growing, perceived policy capacity was stronger.

The availability of relatively inexpensive survey software should lead to similar policy-capacity research in the United States. Moreover, the survey instruments from previous studies could act as blueprints for future studies. Such information would be welcomed by government agencies seeking to advance climate change adaptation policies. Government agencies have traditionally looked to policy capacity research in evaluating their organization's effectiveness. Advising decision makers on how to recalibrate policy tools and tasks needed to enhance climate mainstreaming throughout the policy cycle is a useful outcome of such research. However, organizational cultures and attitudinal barriers can also impede policy work and therefore should also be addressed.

Conclusion: Widening the climate change adaptation research agenda

The Intergovernmental Panel on Climate Change's (IPCC) 2014 report Climate Change 2014: Impacts, Adaptation, and Vulnerability calls for national- and regionallevel efforts to begin undertaking mainstreaming. This document will influence national-level adaptation assessments. The IPCC report highlights climate changerelated risks. For example, a key risk in North America is "wildfire-induced loss of 
ecosystem integrity ... a a a result of increased drying trend and temperature trend" (IPCC 2014: 23). One possible response is to incorporate fire-protection measures (e.g., prescribed burning, introduction of resilient vegetation) into existing policies (IPCC 2014). This review has outlined how an important non-climate change risk, namely a low level of policy capacity, will impede the desired level of mainstreaming. If we do not understand how government agencies develop measures, it will remain unclear if long-term climate change adaptation goals will be realized. Government agencies have gone to great lengths to describe the impacts and vulnerabilities associated with climate change. Typical assessments highlight management recommendations that will promote mainstreaming. However, more needs to be done to guide the decision-makers in actually developing effective and specific policies. This task will fall on the shoulders of the mid-level policy workers who provide policy-relevant data, information, research, and advice to senior managers and decision-makers. Thus, future research should closely examine issues related to policy formulation, such as the interaction of policy actors and policy design.

\section{References}

Bierbaum, R., A. Lee, J. Smith, M. Blair, L. M. Carter, F. S. Chapin III, P. Fleming, S.

Ruffo, S. McNeeley, M. Stults, L. Verduzco, and E. Seyller. 2014. "Chapter 28: A d a p t a tion." In Climate Change Impacts in the United States: The Third National Climate Assessment, edited by J. M. Melillo, Terese (T. C.) Richmond, and G. W. Yohe, 670-706. U.S. Global Change Research Program.

Bierbaum, R., J. B. Smith, A. Lee, M. Blair, L. Carter, F. S. Chapin III, P. Fleming, S. Ruffo, M. Stults, and S. McNeeley. 2013. "A Comprehensive Review of Climate Adaptation in the United States: More Than Before, But Less Than Needed." Mitigation and Adaptation Strategies for Global Change 18:361-406.

Birkland, T. A. 2005. An Introduction to the Policy Process: Theories, Concepts, and Models of Public Policy Making. Armonk: M. E. Sharpe.

Cairney, P. 2014. "How Can Policy Theory Have an Impact on Policy Making? The Role of Theory-Led Academic-Practitioner Discussions.” Teaching Public Administration 1-18. doi: $10.1177 / 0144739414532284$

Chilcote, R. H. 1994. Theories of Comparative Politics. Boulder: Westview Press.

Capano, G. 2011. "Government Continues to Do Its Job: A Comparative Study of Governance Shifts in the Higher Education Sector.” Public Administration 89 (4): 1622-1642.

Colebatch, H. K., and B. A. Radin. 2006. "Mapping the Work of Policy." In The Work of Policy: An International Survey, edited by H. K. Colebatch, 217-226. Oxford: Lexington Books.

Colorado, State of. 2007. Colorado Climate Action Plan: A Strategy to Address Global Warming. November. www.colorado.gov/governor/images/nee/CO_Climate_Action_Plan.pdf. 
Common, R. 2006. "Organisational learning in a political environment: Improving policy-making in UK government.” Policy Studies. 25 (1): 35-49.

Cummings, S., and O. Nørgaard. 2004. "Conceptualizing State Capacity: Comparing Kazakhstan and Kyrgyzstan." Political Studies 52 (4): 685-708.

Davies, P. 2004. "Is Evidence-Based Policy Possible?" The Jerry Lee Lecture, Campbell Collaboration Colloquium, Washington, D.C., February 18-20.

de Bruijn, H., and A. Porter. 2004. "The Education of a Technology Policy Analyst - To Process Management." Technology Analysis and Strategic Management 16 (2): 261-274.

Dessai, S., M. Hulme, R. J. Lempert, and R. Pielke Jr. 2009. "Climate Prediction: A Limit to Adaptation?" In Adapting to Climate Change: Thresholds, Values, Governance, edited by W. N. Adger, I. Lorenzoni, and K. O’Brien. Cambridge: Cambridge University Press.

Dluhy, M. 1981. "Policy Advice-Givers: Advocates? Technicians? Or Pragmatists?” In New Strategic Perspectives on Social Policy, edited by Mila Dluhy, 202-216. New York: Pergamon Press.

Doelle, M., C. Henschel, J. Smith, C. Tollefson, and A. Wellstead. 2012. "New Governance Arrangements at the Intersection of Climate Change and Forest Policy: Institutional, Political and Regulatory Dimensions.” Public Administration 90:37-55.

Dovers, S. R., and R. Hezri. 2010. "Institutions and Policy Processes: The Means to the Ends of Adaptation." Wiley Interdisciplinary Reviews: Climatic Change 1 (2): 212-231.

Dror, Y. 1967. "Policy Analysts: A New Professional Role in Government Service." Public Administration Review 27 (3): 197-203.

Durning, D., and W. Osuna. 1994. "Policy Analysts' Roles and Value Orientations: An Empirical Investigation Using Q Methodology.” Journal of Policy Analysis and Management 13 (4): 629657.

Geyer, R., and S. Rihani. 2010. Complexity and Public Policy. London: Routledge.

Goetz, K. H., and H. Wollmann. 2001. "Governmentalizing Central Executives in Post-Communist Europe: A Four-Country Comparison.” Journal of European Public Policy 8 (6): 864-887.

Goldsmith, S., and W. D. Eggers. 2004. Governing by Network: The New Shape of the Public Sector. Washington, D.C.: Brookings Institution Press.

Halligan, J. 1995. "Policy Advice and the Public Sector." In Governance in a Changing Environment, edited by B. Peters and D. Savoie, 138-172. Montreal: McGill-Queen's University Press.

Hamburger, P., and P. Weller. 2012. "Policy Advice and a Central Agency: The Department of the Prime Minister and Cabinet." Australian Journal of Political Science 47 (3): 363-376.

Head, Brian, Michele Ferguson, Adrian Cherney, and Paul Boreham. 2014. "Are Policy-Makers Interested in Social Research? Exploring the Sources and Uses of Valued Information among Public Servants in Australia." Policy and Society 33 (2): 89-101.

Hicks, R., and P. Watson. 2007. Policy Capacity: Strengthening the Public Service's Support to Elected Officials. Edmonton: Queen's Printer.

Hill, M. 2014. The Policy Process. $6^{\text {th }}$ Edition. New York: Routledge.

Honadle, B. 1981. "A Capacity Building Framework: A Search for Concept and Purpose.” Public Administration Review 41 (5): 575-580.

Hoppe, R., and M. Jeliazkova. 2006. "How Policy Workers Define Their Job: A Netherlands Case Study." In The Work of Policy: An International Survey, edited by H. K. Colebatch, 35-60. Oxford: Lexington Books.

Howlett, M. 2009. "Policy Analytical Capacity and Evidence-Based Policy-Making: Lessons from Canada." Canadian Public Administration 52 (2): 153-175. 
Howlett, M., and J. Craft. 2013. "Policy Advisory Systems and Evidence-Based Policy." In The Evolution of Evidence Based Policy Making in Canada, edited by S. Young, 27-44. Toronto: Oxford University Press.

Howlett, M., and E. Lindquist. 2004. "Policy Analysis and Governance: Analytical and Policy Styles in Canada." Journal of Comparative Policy Analysis 6 (3): 225-249.

Howlett, M., M. Ramesh, and A. Perl. 2009. Studying Public Policy: Policy Cycles and Policy Subsystems. $3^{\text {rd }}$ Edition. Toronto: Oxford University Press.

Howlett, M., and A. Wellstead. 2011. "Policy Analysts in the Bureaucracy Revisited: The Nature of Professional Policy Work in Contemporary Government." Politics and Policy 39:613-633.

- 2012. "The Nature of Policy Work and Policy Capacity at the Sub-National Level: Evidence from Canada's Provinces and Territories." Canadian Public Administration 55 (1): 53 68.

IPCC (Intergovernmental Panel on Climate Change). 2014. "Summary for Policymakers." In Climate Change 2014. Impacts, Adaptation, and Vulnerability. Part A: Global and Sectoral Aspects. Contribution of Working Group II to the Fifth Assessment Report of the Intergovernmental Panel on Climate Change, edited by C. B. Field, V. R. Barros, D. J. Dokken, K. J. Mach, M. D. Mastrandrea,T. E. Bilir, M. Chatterjee, K. L. Ebi, Y. O. Estrada, R. C. Genova, B. Girma, E. S. Kissel, A. N. Levy, S. MacCracken, P. R. Mastrandrea, and L. L.White, 1-32. Cambridge and New York: Cambridge University Press.

Jenkins-Smith, H. 1982. "Professional Roles for Policy Analysts: A Critical Assessment." Journal of Policy Analysis and Management 2 (1): 88-100.

Keane, Robert E., D. F. Tomback, C. A. Aubry, A. D. Bower, E. M. Campbell, C. L. Cripps, M. B. Jenkins, M. F. Mahalovich, M. Manning, S. T. McKinney, M. P. Murray, D. L. Perkins, D. P. Reinhart, C. Ryan, A. W. Schoettle, and C. M. Smith. 2012. A Range-Wide Restoration Strategy for Whitebark Pine (Pinus albicaulis). Gen. Tech. Rep. RMRS-GTR-279. Fort Collins: U.S. Department of Agriculture, Forest Service, Rocky Mountain Research Station.

Koliba, C., and R. Gajda. 2009. "'Communities of Practice' as an Analytical Construct: Implications for Theory and Practice." International Journal of Public Administration 32:97-135.

Lasswell, H. 1970. "The Emerging Conception of Policy Sciences." Policy Sciences 1:3-24.

Lim, B., and E. Spanger-Siegfried. 2004. Adaptation Policy Frameworks for Climate Change: Developing Strategies, Policies and Measures. New York: Cambridge University Press.

Lindquist, E. 1992. "Public Managers and Policy Communities: Learning to Meet New Challenges." Canadian Public Administration 35 (2): 127-159.

Manitoba Office of the Auditor General. 2001. A Review of the Policy Capacity between Departments. Winnipeg: Queen's Printer.

Mayer, I., S. Igor, E. Van Daalen, and P. Bots. 2004. "Perspectives on Policy Analysis: A Framework for Understanding and Design." International Journal of Technology, Policy and Management 4 (1): 169-191.

Meltsner. A. 1976. Policy Analysts in the Bureaucracy. Berkeley: University of California Press.

Ontario Executive Research Group. 1999. Investing in Policy: Report on Other Jurisdictions and Organizations. Toronto: Ministry of the Environment.

Page, E., and B. Jenkins. 2005. Policy Bureaucracy: Governing with a Cast of Thousands. Oxford: Oxford University Press.

Peters, B. G., and J. Pierre, J. 1998. "Governance without Government? Rethinking Public Administration." Journal of Public Administration Research and Theory 8:223-243. 
Prince, M. 2007. "Soft Craft, Hard Choices, Altered Context: Reflections on Twenty-five Years of Policy Advice in Canada." In Policy Analysis in Canada: The State of the Art, edited by L. Dobuzinskis, M. Howlett, and D. Laycock, 219-237. Toronto: University of Toronto Press.

Radin, B. 1997. "Presidential Address: The Evolution of the Policy Analysis Field: From Conversation to Conversations." Journal of Policy Analysis and Management 16 (2): 204-218.

Sabatier, P., and C. Weible. 2014. Theories of the Policy Process. Boulder: Westview Press.

Savoie, D. 2003. "Strengthening the Policy Capacity of Government. Report to the Panel on the Role of Government." Research Paper Series 1:239-290.

Schlager, E., and W. Blomquist. 1996. "A Comparison of Three Emerging Theories of the Policy Process.” Political Research Quarterly 49:651-672.

Simeon, R. 1976. "Studying Public Policy." Canadian Journal of Political Science 9 (4): 548-580.

Stein, B. A., P. Glick, N. Edelson, and A. Staudt (eds.). 2014. Climate-Smart Conservation: Putting Adaptation Principles into Practice. Washington, D.C.: National Wildlife Federation.

USDA Forest Service. 2010. National Road Map for Responding to Climate Change. http://www. fs.fed.us/climatechange/pdf/roadmap.pdf.

- 2011a. A Performance Scorecard for Implementing the Forest Service Climate Change Strategy. http://www.fs.fed.us/climatechange/pdf/ performance_scorecard_final.pdf.

- 2011b. Northwoods Climate Change Response Framework. http://www.nrs.fs.fed.us/niacs/ climate/northwoods/.

Veselý, A. 2013. "Externalization of Policy Advice: Theory, Methodology and Evidence." Policy and Society 32: 199-209.

Weiss, L. 1998. The Myth of the Powerless State. Ithaca: Cornell University Press.

Wellstead, A., M. Howlett, and J. Rayner. 2013. “The Neglect of Governance in Forest Sector Vulnerability Assessments: Structural-Functionalism and "Black Box" Problems in Climate Change Adaptation Planning." Ecology and Society 18 (3): 23.

Wellstead, A., and R. Stedman. 2014. "Addressing the Challenges of Adaptation to Climate Change Policy: Integrating Public Administration and Public Policy Studies." International Journal of Public Administration 37 (14): 999-1010.

Wellstead, A., R. Stedman, and M. Howlett. 2011. "Multi-Level Policy Analytical Capacity in Canada: A Structural Equation Model (SEM) Study of Federal, Provincial and Territorial Policy Analysts and Analysis." Public Policy and Administration 26 (3): 353-373.

Wellstead, A., R. Stedman, and E. Lindquist. 2009. "The Nature of Regional Policy Work in Canada’s Federal Public Service." Canadian Political Science Review 3 (1): 34-56.

Wildavsky, A. 1979. Speaking Truth to Power: The Art and Craft of Policy Analysis. Boston: Little, Brown Publishing.

Wu, X., Ramesh, M., and M. Howlett (Forthcoming). "Blending Skill and Resources Across Multiple Levels of Activity: Competences, Capabilities and the Policy Capacities of Government.” Policy and Society.

Wu, X., M. Ramesh, M. Howlett, and S. Fritzen. 2011. The Public Policy Primer. London: Routledge. 